\title{
Microscopic Anatomy of the Lower Respiratory System of the African Giant Pouched Rat (Cricetomys gambianus, Waterhouse 1840)
}

\author{
Anatomía Microscópica del Sistema Respiratorio Inferior de la \\ Rata Gigante Africana (Cricetomys gambianus, Waterhouse 1840)
}

\author{
C. S. Ibe; B. I. Onyeanusi; S. O. Salami \& J. O. Nzalak
}

IBE, C. S.; ONYEANUSI, B. I.; SALAMI, S. O. \& NZALAK, J. O. Microscopic anatomyof the lower respiratory system of the African giant pouched rat (Cricetomys gambianus, Waterhouse 1840). Int. J. Morphol., 29(1):27-33, 2011.

\begin{abstract}
SUMMARY:A qualitative and quantitative study, by light microscopy, was undertaken on the lower respiratory system of the African Giant pouched rat. Specifically, the trachea, bronchi and lungs were stained with Haematoxylin and eosin, Alcian blue at a pH of 2.5 and Periodic Acid-Schiff stains. Three cell types were identified in saggital sections of the trachea: the ciliated cells, basal cells and mucous cells. Fibers of the trachealis muscles in the laminar propria separated the underlying cartilages from the basal cells. Mucous cells were visible only in the membranous portion of the trachea and they were predominant in the rostral and caudal portion of the trachea. Lobar bronchi consisted of cuboidal epithelium and a layer of one or two smooth muscle cells and opened into segmental bronchi and respiratory bronchiole. Some tracheal cartilaginous rims stained blue with AB while most glandular cells stained red with PAS. The diameter of respiratory bronchiole, alveoli duct and alveoli were $24.93 \mu \mathrm{m}( \pm 1.27), 21.14 \mu \mathrm{m}( \pm 0.66)$ and $12.95 \mu \mathrm{m}( \pm 0.21)$, respectively. These and other findings were compared with similar report in other rodents.
\end{abstract}

KEY WORDS: African Giant pouched rat; Lower respiratory system; Histology.

\section{INTRODUCTION}

The African Giant pouched rat is one of the two members of the genus Cricetomys alongside the Emin's pouched rat (Cricetomys emini). It is among the largest Murids in the world. In Nigeria, an increasing amount of interest is currently expressed on the biology of this wild rodent. This is not surprising because of the catalogue of their importance which has led to their being domesticated. They serve as supplementary protein source for rural dwellers in Nigeria (Ajayi, 1975; Olayemi et al., 2001), thus assisting in food security. They have been successfully used to detect land mines (Mott, 2004) and to diagnose tuberculosis (Maggie, 2003) due to high acuity of odour perception. They also serve as exotic pets (Cooper, 2008) and are proposed as laboratory model of investigation into many physiologic and pathologic conditions (Olayemi \& Adeshina, 2002).

To better understand the African Giant pouched rat, documentation of its anatomy as a basic science pre-requisite for future biomedical investigations is paramount. Thus, several investigators have made pioneering efforts to characterise various systems of this rat in Nigeria. Systems that have been studied include: reproductive (Ogwuegbu et al., 1983; Oke $e t$ al., 1995, 1988a, 1988b; Oke \& Aire, 1989, 1990; Akinloye et al., 2007), digestive (Ali et al., 2008) urinary (Onyeanusi et al., 2007; 2009), skeletal (Olude et al., 2010) nervous (Nzalak et al., 2005; Ibe et al., 2010a; Ibe et al., 2010b), integumentary (Ibe et al., 2010c) and lymphatic (Ibe et al., 2010d).

Histology of the lower respiratory system in other rodents such as the laboratory rat (Spicer et al., 1982; Choi et al., 2000; Widdicombe et al., 2001), hamster (Kennedy et al., 1978), squirrel (Nakakuki, 1979) and guinea pig (Kliment $e t$ al., 1972) have been described in detail. However, such description in the African Giant pouched rat is lacking. The only study found in the literature regarding the respiratory anatomy of the African Giant pouched rat was the gross morphology and morphometry of the conductive bronchial tree reported by Valerius (1996). 
Protective properties of the lower respiratory system are well delineated in the histological features of the system. Goblet cells, which are specialized epithelial cells of conductive airways, secrete mucins in response to inhaled foreign bodies and infectious agents (Rogers, 1994). Goblet cells are also responsible for the formation of ciliated epithelial cells. The respiratory mucus gel, in conjunction with ciliated epithelial cells, forms the mucociliary "escalator," which, along with cough, is essential for the maintenance of sterile and unobstructed airway (Thornton $\&$ Sheehan, 2004). Although the cellular composition of the respiratory epithelium in mammalian airway is basically similar, pronounced differences exist in the distribution pattern of epithelial cell types at the various levels of the airway (Reznik, 1990). These differences have been reported in the regional distribution of tracheal mucous gland in different rodents and other mammals (Goco et al., 1963; Korhonen et al., 1969; Choi et al.; Widdicombe et al.). In some species, tracheal mucous glands are concentrated between the cartilaginous rings, whereas in others, the glands are evenly distributed over and between the rings (Choi et al.). The alveolar epithelium of the lungs is a combination of type I cells that build the air-blood barrier and type II cells that synthesize and secrete surfactant. The lung surfactant proteins $\mathrm{A}$ and $\mathrm{D}$ are part of the pulmonary innate immune system (Wu et al., 2003; Wright, 2004; Jung et al., 2005) and influence inflammatory processes (Chabot et al., 2003; Gardai et al., 2003).

The present study was aimed at documenting the normal microscopic features of the lower respiratory system in the African Giant pouched rat, in order to add to the available information on the anatomy of the rodent. The specific objectives were to describe the histomorphology of the trachea, bronchi and lungs, to describe the regional distribution of the tracheal mucous glands and finally, to compare our findings with similar report in other rodents. This study will serve as a fulcrum for future medical investigations regarding the respiratory system of the African Giant pouched rat.

\section{MATERIAL AND METHOD}

Experimental Animals and Management. Seven clinically healthy African Giant pouched rats with an average weight of $1.07 \mathrm{Kg}$, were utilized for this study. The animals were captured live from the wild in Kaduna State, Nigeria. Locally made traps, constructed into a cages with adequate ventilation and measuring $1.0 \mathrm{~m} \times 0.8 \mathrm{~m} \times 0.8 \mathrm{~m}$ were used. The rats were transported by road to the animal pen in the Department of Veterinary Anatomy, Ahmadu Bello University Zaria,
Nigeria. Here, they were kept in standard laboratory rat cages. They gained maximum acclimatization for one month before commencement of the experiment. During this period, they were physically examined under careful restraint in the cage to ascertain their health status. Un-pilled groundnuts, groundnut cake, raw potatoes and drinking water were provided ad libitum throughout the experimental period.

Tissue Processing. The rats were euthanized by intraperitoneal injection of lethal dose of Thiopental Sodium (Rotexmedica, Trittau. Germany). With the animals on a dorsal recumbency, tracheotomy through the ventral cervical region preceded fixation of the lower respiratory system by intra tracheal instillation of 17 to $20 \mathrm{ml}$ of $10 \%$ phosphatebuffered formalin, using a cannula. When the fixative stopped flowing, the animals were maintained in the same supine position for about four hours. The ventral cervical region and entire thoracic cavity were exposed surgically to reveal the lower respiratory system. The lungs were physically examined and they showed no visual evidence of pathologic conditions. They were also fully expanded. This was evident by the fact that the lobes were closely applied to the walls of the pleural cavity. The lower respiratory system was exteriorized and freed from other thoracic viscera. The trachea, principal bronchi and lungs were separated. These organs were fixed in $10 \%$ phosphate-buffered formalin for three days. Thereafter, the samples were washed in water and kept therein for twenty four hours. Further processing involved dehydration in a series of $70 \%, 80 \%, 90 \%, 95 \%$ and $100 \%$ alcohol in that order, leaving them in each solution of alcohol for an hour. The tissues were cleared in xylene, infiltrated with molten paraffin wax (BDH Chemicals Ltd. Poole, England) at $600 \mathrm{C}$, blocked in paraffin according to standard procedures (Kiernan, 1990) and labelled.

Sagittal and coronal sections of the conductive airway (trachea and principal bronchi) and lungs were cut at $5 \mu \mathrm{m}$ thickness using Jung rotary microtome (Model 42339, Berlin, Germny). The sections were mounted on glass slides, dried, deparaffinized, stained, dehydrated, and coverslipped, using DPX as the mounting medium.

Histomorphological Features. Conductive airway from three samples was sectioned in sagittal and coronal planes for histomorphology. Specifically, three regions of each trachea were processed. These were; the trachea rings just caudal to larynx, mid-tracheal rings and tracheal carina. One section of each principal bronchus was used. These tissues were stained with Haematoxylin and eosin $(\mathrm{H} / \mathrm{E})$, Alcian blue $(\mathrm{AB})$ at a $\mathrm{pH}$ of 2.5 and Periodic Acid-Schiff (PAS). H/E was used to describe the normal architecture of the conductive airway while Alcian blue and PAS were adopted to differentiate between neutral and acidic glycoprotein and polysaccharides. 
Lung tissues from the same three samples were utilized to study the normal histological features of the lungs. Sagittal and coronal sections of the lungs were stained with the conventional H/E. They were also stained with PAS to demonstrate the presence of neutral polysaccharides and glycoproteins and with $\mathrm{AB}$ at a $\mathrm{pH}$ of 2.5 to demonstrate the presence of acidic mucosubstance.

Regional Distribution of Mucous Glands in the Conductive Airway. Trachea and principal bronchi of four samples sectioned in the saggital plane and stained with $\mathrm{AB}$ and PAS were used to determine the regional distribution of tracheal mucous gland. The rostrocaudal extent of each trachea was cut into three parts with a scalpel blade and assigned a serial numeric label. Sagittal sections were obtained by trimming each of these three parts. These sections were then stained and studied on a laptop computer screen with the aid of a digital eyepiece (Scopetek ${ }^{\circledR}$ DCM500, Resolution: 5M pixels) attached to a light microscope (OLYMPUS ${ }^{\circledR}$ - XSZ107BN, Hamburg, Germany). The regions of the tracheal epithelium occupied by glands were traced from the image on the screen. Each slide was shifted to display the adjoining region of section on the screen, and again the epithelial gland profiles were observed. This process was repeated until the entire length of section on the slide was studied. This was repeated for each of the four slides representing one trachea. By this, the distribution of tracheal mucous gland along the rostrocaudal extent and in the ventral and dorsal aspects of the entire tracheal length was studied.

Histomorphometric Analysis. Histological measurements were restricted to the respiratory portion of the lungs. This included the average diameter of 18 respiratory bronchioles, 20 alveoli ducts and 64 alveoli. The diameters of the above structures in a lung section were obtained using a calibrated ocular micrometer (Leitz Wetzlar, Germany) and stage micrometer (Graticules Ltd., London). A magnification factor of $0.37 \mu \mathrm{m}$ was obtained for the $\mathrm{x} 40$ objective lens of the light microscope (OLYMPUS ${ }^{\circledR}$ - XSZ107BN, Hamburg, Germany). This objective lens and the ocular micrometer (Leitz Wetzlar, Germany) were used for the histomorphometry. The respiratory bronchioles and alveoli ducts were defined by the fact that the former does not give off alveolar sacs unlike the latter.

\section{RESULTS}

Histomorphological Features. Histologically, the trachea of the African Giant pouched rat was clearly divided into the membranous and cartilaginous portions (Fig. 1).
Respiratory epithelium was composed of pseudostratified ciliated columnar cells on a basal lamina which contained the basal cells. Below the basal lamina was the lamina propria containing the trachealis muscle which was closely attached to the external surface of the cartilaginous rings and separated the cartilages from the epithelial layer (Fig. 2). The left and right principal bronchi were lined, each with a layer of columnar ciliated epithelial cells. Below the epithelium was a layer of smooth muscle cells. Several short lobar bronchi branched off from the main bronchi. They consisted of cuboidal epithelium and a layer of one or two smooth muscle cells and opened into segmental bronchi and respiratory bronchioles (Fig. 3). The respiratory bronchioles continued as alveolar ducts. The alveolar ducts opened into numerous alveolar sacs (Fig. 3). At a higher magnification (insert in Fig. 3), the respiratory epithelium of the alveoli was observed. This included simple squamous epithelial cells interspaced by simple cuboidal cells. The former were the Type I pneumocytes while the latter were the Type II pneumocytes.

According to Wilson et al. (1983), acidic mucosubstances and polysaccharides stain blue with the $A B$ stain at a $\mathrm{pH}$ of 2.5 while the neutral mucosubstances and polysaccharides stain red with the PAS stain. In utilizing this principle, we realized that some trachea cartilaginous rims stained blue with $\mathrm{AB}$ while most glandular cells stained red with PAS.

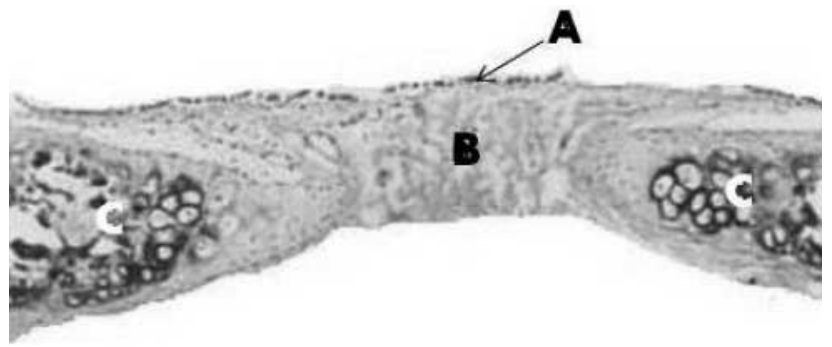

Fig. 1. Saggital section of the proximal trachea of the African Giant pouched rat, illustrating A: Epithelial cells. B: Membranous part with numerous mucous glands. C: Cartilaginous part. H/E X 100

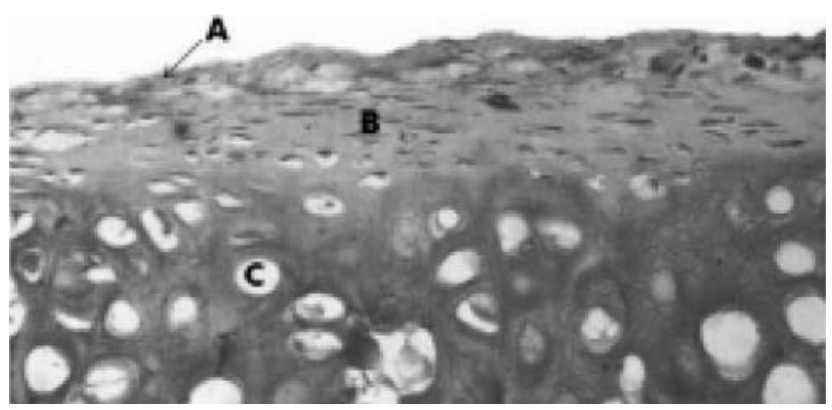

Fig. 2. Saggital section of the proximal trachea of the African Giant pouched rat, illustrating A: Respiratory epithelium. B: Trachealis muscle. C: Cartilage. PAS X 400 


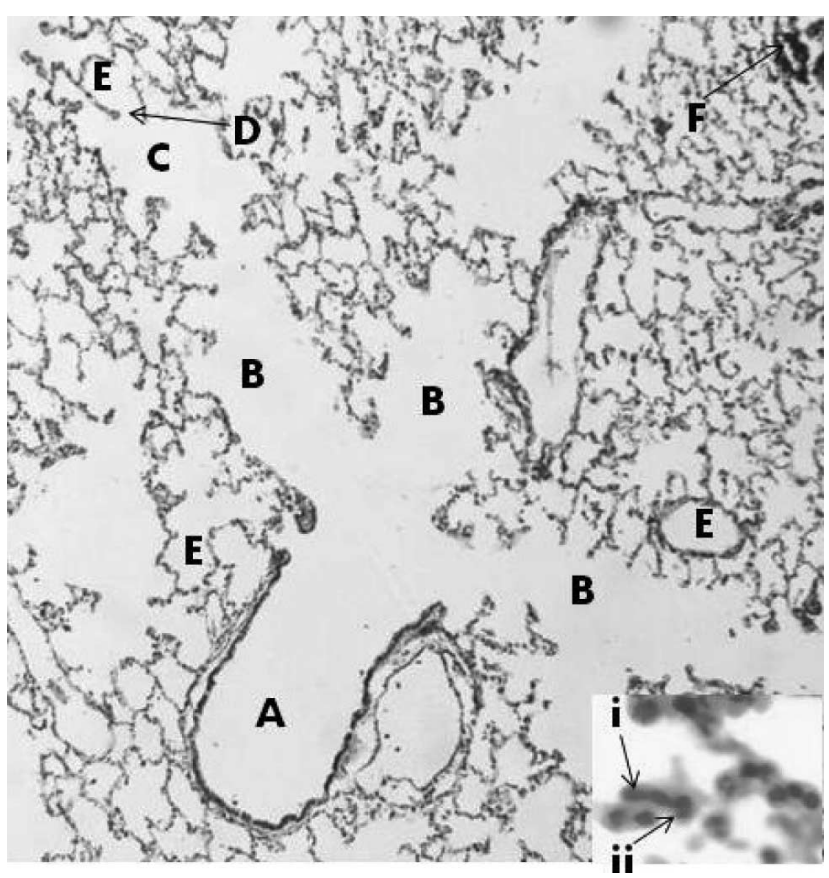

Fig. 3. Coronal section of lung tissue of the African Giant pouched rat, illustrating the branching pattern from segmental bronchus to the alveoli spaces. A: lobar bronchus. B: Segmental bronchus. C: Respiratory bronchiole. D: Alveoli duct. E: Alveoli spaces. F: Pulmonary artery. H/E X 100. Insert shows Type I (i) and Type II (ii) pneumocytes at $\mathrm{X} 400$.

Regional Distribution of Tracheal Mucous Gland. There was no significant difference in the regional distribution of mucous glands between the African Giant pouched rats. In the sagittal sections, mucous glands were predominant in the rostral trachea than the caudal trachea. The carina was free of mucous glands. The glands were predominant in the membranous portion, between the cartilaginous rings (Fig. 1). The cartilages were devoid of glands. They were more glands on the ventral surface compared to the dorsal surface of the trachea.

Histomorphometric Assessment. The result of the average diameters of the segmental bronchi, respiratory bronchioles and alveoli spaces were represented in Table I with the number of counted structures in parentheses. The average length of the 5 segmental bronchi was $38.428 \mu \mathrm{m}$ $( \pm 0.890)$ with a range of $36.26 \mu \mathrm{m}$ to $40.70 \mu \mathrm{m}$.

\section{DISCUSSION}

One of the major functions of tracheal and bronchial epithelium is mucociliary clearance of inhaled harmful particles. This important lung-protective function depends both on the availability and subsequent efficiency of mucosal glands, and ciliary actions. Choi et al. recorded a linear relationship between tracheal diameter and number of mucous glands in mammals and concluded that increased size of conductive airway (marked by increased tracheal diameter) results to an increased inflow velocity of inspired air which culminates in an increased rate of foreign body deposition. Since the mucus produced by the glands are involved in trapping inhaled foreign bodies which are subsequently expelled by mucociliary escalator (Thornton \& Sheehan), animals with higher tracheal diameter have more mucous glands than those with smaller diameter because of the higher tendency of foreign body deposition. Ibe et al. (2011) recorded a tracheal diameter of $5.44 \mathrm{~mm}( \pm 0.03)$ with an average of $5.32 \mathrm{~mm}$ in the rostral trachea in the African Giant pouched rat. In the present study, tracheal mucous glands were predominant in the rostral trachea. This agrees with the linear relationship reported by Cho et al. Widdicombe et al. did not record any tracheal gland in mice and attributed this to their small tracheal diameter of approximately $1 \mathrm{~mm}$. They observed tracheal glands in other rodents such as hamster, rat and guinea pig with wider tracheal diameter of approximately $1.5 \mathrm{~mm}, 2.5 \mathrm{~mm}$ and $2.5 \mathrm{~mm}$ respectively.

The present study recorded more mucous glands on the rostral than caudal portion of the trachea, on the dorsal than the ventral surface of the trachea, and on the membranous but not cartilaginous portion of the trachea in the African Giant pouched rat. This is similar to what was recorded for the laboratory rat by Hayashi et al. (1979) Spicer et al.; Ohtsuka et al. (1997), Choi et al. and Widdicombe et al. Similarly, Kennedy et al. and Reznik reported that mucous glands were primarily in the rostral portion of the trachea of hamsters, near the larynx. Conversely, Choi et al. reported absence of mucous gland in the entire trachea epithelium of the rabbit and presence of mucous glands only at the border between the trachea and larynx in the mouse. This is not similar to what was obtained in the present study for the African giant pouched rat.

Table I. Sizes of airway structures in the African Giant pouched rat.

\begin{tabular}{lccc}
\hline Structure & Minimum diameter $(\mu \mathrm{m})$ & Maximum diameter $(\mu \mathrm{m})$ & Mean diameter $(\mu \mathrm{m})( \pm \mathrm{SEM})$ \\
\hline Respiratory bronchioles $(18)$ & 21.40 & 27.76 & $24.93( \pm 1.27)$ \\
Alveolar ducts (20) & 18.51 & 25.40 & $21.14( \pm 0.66)$ \\
Alveoli (64) & 11.48 & 16.29 & $12.95( \pm 0.21)$ \\
\hline
\end{tabular}


The tracheal epithelium recorded in the present study is similar to that of other rodents as reported by Reznik. However, Kennedy et al. stated that the respiratory epithelium in the Syrian golden hamster ranged from ciliated pseudostratified columnar to low columnar epithelium with goblet cells. This is not similar to the result of the present study in which respiratory epithelium in saggital sections of the trachea revealed a consistent pattern of pseudostratified ciliated columnar cells.

Kennedy et al. recorded an average alveoli diameter of $0.06 \mathrm{~mm}$, equivalent to $60 \mu \mathrm{m}$ in the adult golden Syrian hamster. They also recorded an average diameter of $130 \mu \mathrm{m}$ and $160 \mu \mathrm{m}$ for the alveolar duct and respiratory bronchioles, respectively. These values are very high, compared to the values we obtained in the African Giant pouched rats. The Syrian Golden hamster is smaller in size than the African Giant pouched rat. They have an average bodyweight of 125 $\mathrm{g}$ (Kennedy et al.) as against the $1065 \mathrm{~g}$ recorded in the African Giant pouched rat. This finding supports the initial report of Ibe et al. (2011) that the respiratory system of the African Giant pouched rat is not well developed and thus, less efficient when compared to that of other smaller rodents. The works of Lindstedt (1984) and Valerius have also supported this negative correlation between body weight and size of respiratory organs. The effect of the poorly developed respiratory system to the habitat and life style of the African giant pouched rat has been discussed.

\section{CONCLUSION}

In the present study, histological features of the lower respiratory system in the African Giant pouched rat were observed in detail. In results of the examination, it was suggested that the lower respiratory system in the African Giant pouched rat was almost similar to that of the hamster and some other rodents except for the smaller sizes of the alveoli, alveolar ducts and respiratory bronchi, when compared to those of the Syrian golden hamster. Thus, the lower respiratory system in the African Giant pouched rat can be used as a model of the rodent respiratory system histology in phylogenetic studies.

IBE, C. S.; ONYEANUSI, B. I.; SALAMI, S. O. \& NZALAK, J. O. Anatomía microscópica del sistema respiratorio inferior de la rata gigante africana (Cricetomys gambianus, Waterhouse 1840). Int. J. Morphol., 29(1):27-33, 2011.

RESUMEN: Se realizó un estudio cualitativo y cuantitativo, mediante microscopía de luz, en el sistema respiratorio inferior de la rata gigante Africana. La tráquea, los bronquios y los pulmones fueron teñidos con hematoxilina y eosina, azul Alcián a pH de 2,5 y ácido periódico de Schiff. Tres tipos de células fueron identificadas en las secciones sagitales de la tráquea: células ciliadas, basales y mucosas. Las fibras del músculo traqueal en la propia laminar separados los cartílagos subyacente de las células basales. las células mucosas son visibles sólo en la porción membranosa de la tráquea y predominan en la parte rostral de la porción caudal de la tráquea. Los bronquios lobares consistían en epitelio cúbico y una capa de una o dos células de músculo liso y abierto en los bronquios y bronquiolos segmentarios respiratorias. Algunos bordes azules cartilaginoso traqueal manchada con AB, mientras que la mayoría de las células glandulares teñido de rojo con PAS. El diámetro de los bronquiolos respiratorios, conductos alveolares y los alvéolos fueron $24,93 \mathrm{~m}( \pm$ $1,27), 21,14 \mathrm{~m}( \pm 0,66)$ y $12,95 \mathrm{~m}( \pm 0,21)$, respectivamente. Estos y otros resultados se compararon con el informe similar en otros roedores.

PALABRAS CLAVE: Rata gigante africana; Sistema respiratorio inferior; Histología.

\section{REFERENCES}

Ajayi, S. S. Observations on the biology, domestication and reproductive performance of the African Giant rat (Cricetomys gambianus, Waterhouse) in Nigeria. Mammalia, 39:343-64, 1975.

Akinloye, A. K., Oke, B. O. \& Soley, J. T. Ultrastructural features of the vagina at different phases of oestrus cycle in the female African giant rats (Cricetomys gambianus, Waterhouse). Proceedings of the $44^{\text {th }}$ Annual Congress of the Nigerian Veterinary Medical Association (NVMA), 112-6, 2007.
Ali, M. N., Byanet, O., Salami, S. O., Imam, J., Maidawa, S. M., Umosen, A. D., Alphonsus, C. \& Nzalak, J. O. Gross anatomical aspects of the gastro-intestinal tract of the wild African Giant pouched rat (Cricetomys gambianus). SRE, 3 (10):518-20, 2008.

Chabot, S., Salez, L., McCormack, F. X., Touqui, L. \& Chignard, M. Surfactant protein A inhibits lipopolysaccharide-induced in vivo production of interleukin-10 by mononuclear phagocytes during lung inflammation. Am. J. Respir. Cell Mol. Biol., 28:347-53, 2003. 
Choi, H. K., Finkbeiner, W. E. \& Widdicombe, J. H. A comparative study of mammalian tracheal mucous glands. J. Anat., 197:361-72, 2000.

Cooper, R. G. Care, husbandry and diseases of the African Giant rat (Cricetomys gambianus). J. S. Afr. Vet. Med. Assoc., 79(2):62-6, 2008.

Gardai, S. J., Xiao, Y. Q., Dickinson, M., Nick, J. A., Voelker, D. R., Greene, K. E. \& Henson, P. M. By binding SIRP alpha or calreticulin/CD91, lung collectins act as dual function surveillance molecules to suppress or enhance inflammation. Cell, 115:13-23, 2003.

Goco, R. V., Kress, M. B. \& Brantigan, O. C. Comparison of mucus glands in the tracheobronchial tree of man and animals. Annals of the New York Academy of Sciences, 106:555-71, 1963.

Hayashi, M., Sornberger, G. C. \& Huber, G. L. Morphometric analyses of tracheal gland secretion and hypertrophy in male and female rats after experimental exposure to tobacco smoke. Am. Rev. Respir. Dis., 119:67-73, 1979.

Ibe, C. S., Onyeanusi, B. I., Ayo, J. O., Salami, S. O. \& Ajayi, I. E. Preliminary neuroanatomical study of the visual and auditory senses in the African Giant pouched rat (Cricetomys gambianus Waterhouse-1840). Proceedings of the $35^{\text {th }}$ Annual Conference of the Nigerian Society for Animal Production (NSAP), pp. 134-137, 2010a.

Ibe, C. S., Onyeanusi, B. I., Hambolu, J. O. \& Ayo, J. O. Sexual dimorphism in the whole brain and brainstem morphometry in the African Giant pouched rat (Cricetomys gambianus, Waterhouse - 1840). Folia Morphol. 69 (2)(in press, 2010b).

Ibe, C. S., Onyeanusi, B. I., Salami, S. O. \& Ajayi, I. E. Adaptive morphology of the mystacial vibrissae in the African giant pouched rat (Cricetomys gambianus, Waterhouse-1840). J. Vet. Anat. 3 (2):35-46, 2010 c.

Ibe, C. S., Onyeanusi, B. I. Nzalak, J. O. \& Ajayi, I. E. On the structure of the spleen in the African Giant pouched rat (Cricetomys gambianus, Waterhouse 1840). Vet. Res. 3 (4):70-4, 2010 d.

Ibe, C. S., Salami, S. O. \& Onyeanusi, B. I. Macroscopic anatomy of the lower respiratory system in a nocturnal burrowing rodent: African giant pouched rat (Cricetomys gambianus, Waterhouse 1840). Anat. Histol. Embryol. 40(2):112-119, 2011.
Jung, A., Allen, L., Nyengaard, J. R., Gundersen, H. J. G., Richter, J., Hawgood, S. \& Ochs, M. Design-based stereological analysis of the lung parenchymal architecture and alveolar Type II cells in surfactant protein A and D double deficient mice. Anat. Rec., 286A: 885-90, 2005.

Kennedy, A. R., Desrosiers, A., Terzaghi, M. \& Little, J. B. Morphometric and histological analysis of the lungs of Syrian golden hamsters. J. Anat., 125:527-53, 1978.

Kiernan, J. A. Histological and histochemical methods: theory and practice. Oxford Per-gamon Press, 1990. pp. 320-344.

Kliment, V., Libich, J. \& Kaudersova, V. Geometry of guinea pig respiratory tract and application of Landahl's model of deposition of aerosol particles. J. Hyg. Epidemiol. Microbiol. Immunol., 16:107-14, 1972.

Korhonen, L. K., Holopainen, E. \& Paavolainen, M. Some histochemical characteristics of tracheobronchial tree and pulmonary neoplasms. Acta Histochem., 32:57-73, 1969.

Lindstedt, S. L. Pulmonary transit time and diffusing capacity in mammals. Am. J. Physiol. Regul. Integr. Comp. Physiol., 246:384-8, 1984.

Maggie, M. Giant Rats to Sniff Out Tuberculosis. In: http/ :www.NewScientist.com news service. 2003. Accessed: 16/12/2008. 17:33:32 GMT.

Mott, M. Bees, Giant African rats used to sniff landmines. National Geographic news. In: http:// news.nationalgeographic.com. 2004. Accessed: 11/09/ 2009. 07: 20: 34 GMT.

Nakakuki, S. Lung of the Formosan squirrel. Anat Anz., 146(2):152-5, 1979.

Nzalak, J. O., Ayo, J. O., Neils, J. S., Okpara, J. O., Onyeanusi, B. I., Ghaji, A. \& Ojo, S. A. Morphologic Studies of the Cerebellum and Forebrain of the African giant rat (Cricetomys gabianus). Trop. Vet., 23:87-92, 2005.

Ogwuegbu, S. O., Oke, B. O. \& Aire, T. A. Histomorphometric, histochemical and microstereological studies of the accessory glands of the male African Giant rat (Cricetomys gambianus, Waterhouse) in Ibadan, Nigeria. Afr. J. Ecol., 21:32933, 1983. 
Ohtsuka, R., Doi, K. \& Itagaki, S. Histological characteristics of respiratory system in Brown Norway rat. Exp. Anim., 46:127-33, 1997.

Oke, B. O \& Aire, T. A. Ultrastrucural evidence of secretion in different zones of the caput epididymis of the African giant rat (Cricetomys gambianus waterhouse). Vet. Archiv., 60:207-12, 1990.

Oke, B. O. \& Aire, T. A. The bulbourethral gland of Africa giant the giant rat (Cricetomys gambianus Waterhouse) Vet. Archiv,. 59:267-74, 1989.

Oke, B. O., Aire, T. A., Adeyemo, O. \& Heath, E. The structure of the epididymis of the African giant rat (Cricetomys gambianus Waterhouse). Histological, histochemical and microsteriological studies. J. Anat., 160:9-19, 1988a.

Oke, B. O., Aire, T. A., Adeyemo, O. \& Heath, E. The ultra structure of the epididymis of the African giant rat (Cricetomys gambianus Waterhouse). J. Anat., 165:75$85,1988 \mathrm{~b}$.

Oke, B. O., Oke, O. A. \& Aire, T. A. The prostate gland of the African Giant rat (Cricetomys gambianus Waterhouse). Vet. Arhiv., 65:115-25, 1995.

Olayemi, F. \& Adeshina, E. Plasma biochemical values in the African Giant rat (Cricetomys gambianus, Waterhouse) and the West African hinge backed tortoise (Kinixys erosa). Vet. Arhiv., 72:335-42, 2002.

Olayemi, F. O., Oke, O. A., Oyewale, J. O. \& Ogunsanmi, A. O. The effect of season on the blood profile of the African Giant rat (Cricetomys gambianus, Waterhouse). Israel Journal of Veterinary Medicine. 56 (4). In: http:/ /www.isrvma.org/article/56_4.htm. 2001. Accessed: 27/ 07/2007. 05:30:23 GMT.

Olude, M. A., Olopade, J. O., Fatola, I. O. \& Onwuka, S. K. Some aspects of the neurocraniometry of the African giant rat (Cricetomys gambianus Waterhouse), Folia Morphol., 68(4):224-7, 2009.

Onyeanusi, B. I., Adeniyi, A. A., Ayo, J. O. \& Nzalak, J. O. Morphometric studies of the kidneys of the African giant rat (Cricetomys gambianus Waterhouse). JAVA, 6(11):1273-6, 2007.

Onyeanusi, B. I., Adeniyi, A. A., Ayo, J.O., Ibe, C. S. \& Onyeanusi, C. G. A comparative study on the urinary system of the African Giant rat (Cricetomys gambianus
Waterhouse) and the Wistar rat. Pak. J. Nutr., 8(7):10437, 2009.

Reznik, G. K. Comparative anatomy, physiology and function of the upper respiratory tract. Environ Health Perspect., 85:171-6, 1990.

Rogers, D. F. Airway goblet cells: responsive and adaptable front-line defenders. Eur. Respir. J., 7:1690-706, 1994.

Spicer, S. S., Setser, M. E., Mochizuki, I. \& Simson, J. A. V. The histology and fine structure of glands in the rat respiratory tract. Anat. Rec., 202:33-43, 1982.

Thornton, D. J. \& Sheehan, J. K. From mucins to mucus. Toward a more coherent understanding of this essential barrier. Proc. Am. Thorac. Soc., 1:54-61, 2004.

Valerius, K. Size-dependent morphology of the conductive bronchial tree in four species of Myomorph rodents. $J$. Morphol., 230:291-7, 1996.

Widdicombe, J. H., Chen, L. L-K., Sporer, H., Choi, H. K., Pecson, I. S. \& Bastacky, S. J. Distribution of tracheal and laryngeal mucous glands in some rodents and the rabbit. J. Anat., 198:207-21, 2001.

Wilson, T. S., McDowell, E. M. \& Trump, B. F. An Alcian Blue ( $\mathrm{pH}$ 2.5)-Pas-Keratin Immunoperoxidase Method for the Simultaneous Demonstration of Keratin and Neutral and Acidic Mucosubstances. Biotech Histochem., 58:225-9, 1983.

Wright, J. R. Host defence functions of pulmonary surfactant. Biol. Neonate, 85:326-32, 2004.

Wu, H., Kuzmenko, A., Wan, S., Schaffer, L., Weiss, A., Fisher, J. H., Kim, K. S. \& McCormack, F. X. Surfactant proteins A and D inhibit the growth of gram-negative bacteria by increasing membrane permeability. J. Clin Invest., 111:1589-602, 2003.

\section{Correspondence to:}

Dr. Chikera Samuel Ibe

Department of Veterinary Anatomy

Ahmadu Bello University

Zaria

NIGERIA

Phone: +2348032882105

Email: writechikera@yahoo.com

Received: 22-05-2010 Accepted: 16-12-2010 